\title{
KOMBINASI VOICE NOTE DAN MIND MAPPING DALAM PEMBELAJARAN BAHASA INDONESIA SECARA DARING DI MASA PANDEMI COVID 19
}

\author{
Rina Susi Cahyawati ${ }^{1}$ \\ ${ }^{1}$ Program Studi Pendidikan \\ Biologi, Fakultas Sains dan \\ Teknologi, Universitas Islam \\ Negeri WalisongoSemarang \\ Jl. Prof. Dr. Hamka KM. 2 \\ Ngaliyan Semarang Jawa \\ Tengah 50181
}

Correspondence: Rina Susi Cahyawati rina.susi@walisongo.ac.id

\begin{abstract}
Online learning is one of the alternative solutions set by the government in an effort to carry out an educational climate during the Covid-19 pandemic. Online learning patterns at least require teachers to try to find ways to make distance learning fun and can meet the needs of students for scientific material. The combination of voice notes and mind mapping is an alternative that can be used as a means and media for online learning. The assumption is that most of the participants currently have a WhatsApp application so that it will not make it difficult for them with regards to devices or quotas. Meanwhile, for making mind mapping students can make their versions according to their respective versions so that they will get the sensation of learning while playing. Therefore, the problems of this article are Indonesian language learning technical with a combination of voice notes and mind mapping; and strengths and weaknesses of the implementation of learning Indonesian with a combination of voice notes and mind mapping. The research method used is descriptive qualitative with content analysis. The result of the research is that a combination of voice notes and mind mapping can be used for learning Indonesian online by following the proper technical implementation. The combination of the two has a positive and negative impact on learning.
\end{abstract}

Keywords: Voice Note, Mind Mapping, Indonesian Language Learning

\begin{abstract}
Abstrak: Pembelajaran daring merupakan salah satu solusi alternatif yang ditetapkan pemerintah sebagai upaya menjalankan iklim pendidikan di masa pandemi Covid-19. Pola pembelajaran daring setidaknya menuntut tenaga pengajar untuk berupaya mencari cara agar pembelajaran jarak jauh tetap menyenangkan dan dapat memenuhi kebutuhan peserta didik akan materi keilmuan. Kombinasi voice note dan mind mapping adalah salah satu alternatif yang dapat dimanfaatkan sebagai sarana dan media pembelajaran secara daring. Asumsinya, sebagian besar peserta saat ini sudah memiliki aplikasi WhatsApp sehingga tidak akan menyulitkan mereka ihwal gawai maupun kuota. Sementara itu, untuk pembuatan mind mapping dapat dibuat peserta didik menurut versi masing-masing sehingga mereka akan memeroleh sensasi belajar sambil bermain. Oleh karena itu, masalah dalam artikel: teknis pembelajaran bahasa Indonesia dengan kombinasi voice note dan mind mapping, dan kelebihan dan kelemahan pelaksanaan pembelajaran bahasa Indonesia dengan kombinasi voice note dan mind mapping. Metode penelitian yang digunakan deskriptif kualitatif melalui konten analisis. Hasil penelitiannya adalah kombinasi voice note dan mind mapping dapat digunakan untuk pembelajaran bahasa Indonesia secara daring dengan mengikuti teknis pelaksanaan dengan tepat. Kombinasi keduanya memberikan dampak positif dan negatif dalam pembelajaran.
\end{abstract}

Kata Kunci: Pesan Suara, Peta Konsep, Pembelajaran Bahasa Indonesia 


\section{1 | PENDAHULUAN}

Covid-19 masih menjadi topik aktual. Semenjak ditemukan fakta bahwa virus ini memiliki keunggulan yaitu sistem penularannya yang begitu cepat sehingga menyebabkan banyak korban, maka Pemerintah Indonesia melalui Keputusan Presiden Nomor 12 Tahun 2020 tanggal 13 April 2020 menetapkan bahwa pandemi Covid-19 menjadi bencana nasional non alam (Ering, 2020; Sulhin, 2020). Pandemi Covid 19 memberikan dampak yang besar bagi kelangsungan bidangbidang strategis seperti kesehatan, perekonomian, bahkan pendidikan. Sebagai langkah pencegahan penularan virus ini, pemerintah telah menyosialisasikan protokol kesehatan yang harus dipatuhi oleh seluruh rakyat.

Salah satu isi protokol kesehatan tersebut adalah dengan menghindari kerumuman. Oleh karena itu, kegiatan yang melibatkan banyak orang dalam satu lokasi yang sangat tidak dianjurkan. Salah satu imbasnya dunia pendidikan, aktivitas pembelajaran di sekolah yang memang melibatkan banyak orang dalam satu tempat yang akhirnya harus dialihkan menjadi pembelajaran secara jarak jauh yang tetap diselenggarakan tetapi dari rumah masing-masing. Hal ini senada dengan pernyataan Abidah et al., 2020 yang menyatakan bahwa penyelenggaraan kegiatan belajar mengajar yang tidak seperti biasanya yaitu dengan pemberlakukan pembelajaran jarak jauh oleh semua lembaga pendidikan diharapkan dapat mengurangi penyebaran Covid-19.

Pembelajaran secara daring (dalam jaringan) merupakan salah satu solusi yang ditetapkan pemerintah sebagai upaya untuk tetap menggerakkan roda pendidikan di masa pandemi. Pembelajaran daring merupakan bentuk adaptasi aktivitas pembelajaran di masa pandemi. Hal ini sejalan dengan pendapat Juniartini dan Rasna yang menyatakan bahwa sebagian besar perusahaan dan lembaga pendidikan beradaptasi dengan menetapkan aktivitas work from home dan juga membuat sistem belajar online untuk siswa maupun mahasiswa (Fahmi, 2020; Juniartini, 2020). Pembelajaran dengan mengandalkan segala bentuk sarana dan prasarana yang memungkinkan terjadinya aktivitas pembelajaran secara jarak jauh ini dikenal masyarakat dengan istilah yang berbeda-beda seperti pembelajaran online, pembelajaran daring, pembelajaran jarak jauh (PJJ), atau belajar dari rumah. Meskipun dikenal dengan istilah yang beragam, tetapi pada hakikatnya esensi pembelajaran daring adalah sama yaitu aktivitas pembelajaran yang dilaksanakan secara jarak jauh baik antara guru dengan peserta didik maupun antara peserta didik satu dengan lainnya.

Pembelajaran daring memiliki karakteristik yang membedakannya dengan pembelajaran luring (luar jaringan). Karakteristik tersebut terkait perangkat pendukung yang digunakan serta kemampunan pengoperasiannya. Pernyataan tersebut sejalan dengan pandangan Nilasari (2020) yang menyatakan bahwa dalam pembelajaran daring guru dan peserta didik harus memiliki kemampuan dalam mengoperasikan perangkat teknologi informasi komputer (TIK); memiliki ketersediaan bahan ajar sederhana tetapi tepat guna seperti komputer jinjing, gawai, maupun komputer; serta terhubung dengan jaringan internet yang kuat. Sinergi hal-hal tersebut dapat membantu kelancaran pembelajaran daring.

Telah disampaikan di awal bahwa dalam pembelajaran daring membutuhkan perangkat pendukung komunikasi jarak jauh seperti telepon pintar (smart phone) maupun laptop. Jika dilihat secara umum memang jumlah peserta didik yang memiliki telepon pintar jauh lebih banyak jika dibandingkan dengan yang memiliki laptop. Oleh karena itu, guru lebih memfokuskan aktivitas pembelajaran dengan mengefektifkan penggunaan aplikasi yang umumnya ada pada telepon pintar mereka.

Stigma yang muncul di masyarakat adalah bahwa pembelajaran daring kurang terkontrol dan menimbulkan kejenuhan. Oleh karena itu, salah satu alteratif solusi yang dapat diterapkan guru dalam upaya menghapus atau setidaknya meminimalisasi stigma tersebut adalah dengan memilih 
media maupun metode yang sesuai. Menurut Ernawati (2020), ada beberapa prinsip yang menjadi pertimbangan guru ketika akan memilih media pembelajaran yang sesuai dengan tujuan belajar, yaitu: (1) guru harus dapat menggunakan media pembelajaran tersebut agar tujuan pembelajaran dapat optimal; (2) memilih pembelajaran yang menarik sekaligus menampung kebutuhan peserta didik sesuai dengan situasi dan kondisi; (3) media pembelajaran haruslah efektif; dan (4) guru harus dengan baik menguasai media yang akan dipakai.

WhatsApp merupakan salah satu aplikasi komunikasi yang dimiliki oleh sebagian besar pengguna telepon pintar. WhatsApp dapat dikategorikan sebagai bagian dari mobile learning disamping efek aplikasi ini yang mengandung komodifikasi waktu (Setiyaningsih, \& Jatmikowati, 2019) dan juga memberikan efek media panics di era pandemi (Setiyaningsih, 2020). Menurut O'Malley dalam Purbasari (2013), mobile learning merupakan suatu aktivitas pembelajaran yang menjadikan pebelajar (learner) memanfaatkan perangkat teknologi yang dapat diakses di berbagai lokasi sehingga menurut Dewanta (2019) mereka tidak perlu belajar pada ruang dan waktu yang sama.

WhatsApp memiliki berbagai fungsi. Panggilan telepon, panggilan video (video call), fitur status, fasilitas stiker dan emoji, pengiriman gambar dan video, serta pesan audio (voice note) adalah fasilitas yang ditawarkan oleh aplikasi ini. Dalam Nurazizah et al., (2019) menyatakan bahwa WhatsApp merupakan suatu aplikasi pesan instan dengan berbasis pada telepon pintar dan jaringan internet yang memungkinkan penggunanya untuk bertukar informasi secara jarak jauh dengan berbagai fitur seperti teks, gambar, video, dan pesan audio (voice note). Dengan fungsinya yang beragam maka WhatsApp dinilai dapat dimanfaatkan dalam aktivitas pembelajaran daring pada masa pandemi Covid-19.

Voice note (pesan suara/pesan audio) merupakan fitur dalam WhatsApp. Selain mudah dalam penggunaannya fitur ini memiliki kelebihan yaitu dapat menyampaikan pesan- pesan yang cukup panjang tanpa harus berlama-lama dalam pengetikkannya. Selain itu, voice note memungkinkan pengirim dan penerima pesan untuk menyimpan pesan dan memutar ulang sewaktu-waktu dibutuhkan. Dalam pembelajaran, fitur ini dapat memudahkan guru dalam menyampaikan materi, menyampaikan instruksi, menjelaskan secara detail. Selain itu, voice note dapat dijadikan sebagai sarana bagi peserta didik jika ingin mengemukakan pendapat, bertanya, ataupun memberikan tanggapan lain secara cepat dan lengkap (Sahidillah, \& Miftahurrisqi, 2019).

Kombinasi antara voice note dengan mind mapping dinilai tepat untuk pembelajaran daring karena keduanya memiliki hubungan komplementer. Mind mapping merupakan metode yang berperan sebagai acuan materi yang disampaikan sehingga lebih fokus pada hal-hal yang dianggap penting dan membutuhkan penjelasan lebih. Sementara voice note merupakan sarana yang memperjelas isi materi yang telah ditulis dalam mind mapping. Pada pembelajaran daring keberadaan peserta didik dan guru yang tidak pada satu lokasi berpotensi menimbulkan kesalahpahaman makna apabila dalam penyampaian materi hanya disampaikan dengan pesan tertulis. Kelebihan dalam bahasa lisan adalah ada penjedaan dan penekanan dalam penyampaiannya sehingga mengurangi risiko salah persepsi. Dengan sifat yang demikian itu maka voice note dapat diaplikasikan dalam aktivitas pembelajaran daring.

Pembelajaran bahasa Indonesia tidak terlepas pada pembelajaran berbasis teks. Secara sederhana aktivitas yang dilakukan dalam pembelajaran bahasa Indonesia adalah penyampaian materi, penguatan teori, dan dilanjutkan dengan praktik menulis hingga tercipta produk berupa teksteks yang diajarkan. Pembelajaran dengan pola semacam ini memiliki tingkat kesulitan tersendiri ketika disampaikan secara daring karena dengan segala keterbatasan guru harus bisa menyampaikan materi dengan baik.

Kombinasi voice note sebagai media dan mind mapping sebagai metode dalam pembelajaran bahasa Indonesia merupakan salah satu alternatif yang dapat dimanfaatkan sebagai sarana 
pembelajaran daring. Asumsinya, sebagian besar peserta saat ini sudah memiliki aplikasi WhatsApp sehingga tidak menyulitkan mereka ihwal aplikasi gawai maupun kuota. Sementara itu, untuk pembuatan mind mapping dapat dibuat peserta didik menurut versi masing-masing sehingga akan diperoleh sensasi belajar sambil bermain dengan gambar dan warna. Sebagaimana yang disampaikan Areeisty et al., (2020) menyatakan bahwa mind mapping dapat membantu peserta didik dalam upaya memahami suatu khasanah keilmuan maupun informasi dengan menambahkan gambar dan warna.

Berdasarkan sifatnya mind mapping tepat diaplikasikan dalam pembelajaran bahasa Indonesia khususnya dalam mengembangkan keterampilan menulis. Hal ini karena mind mapping dapat membantu siswa dalam menyusun gambaran besar ide dan gagasan pokok peserta didik serta menggunakan kata-kata kunci untuk menjabarkan poin-poin penting lain yang diperoleh dari hasil percabangan ide utama tersebut (Kuncoro, 2015). Pencatatan hal-hal yang dianggap penting dan utama memudahkan peserta didik dalam proses penyerapan materi sebagai bekal menulis suatu teks.

Melihat adanya kesesuaian antara voice note dan mind mapping dalam pembelajaran daring maka kombinasi keduanya dapat digunakan dalam pembelajaran. Namun, perlu disesuaikan juga dengan mata pelajaran dan materi yang disampaikan. Sebenarnya keduanya sudah pernah digunakan dalam pembelajaran bahasa. Namun, voice note maupun mind mapping masih digunakan sebagai media atau metode tunggal. Penelitian yang menggabungkan voice note dengan mind mapping dalam pembelajaran bahasa Indonesia di masa pandemi ini dapat dikategorikan sebagai hal baru. MTsN 4 Boyolali merupakan sekolah yang pernah menerapkan keduanya pada mata pelajaran bahasa Indonesia kelas IX tahun pelajaran 2020/2021. Kombinasi tersebut digunakan dalam upaya penyampaian materi dan penguatan teori pada bidang kajian teks laporan percobaan.

Ada beberapa penelitian terdahulu yang berkenaan dengan pembelajaran bahasa Indonesia dan aplikasi WhatsApp. Kaitannya dengan pembelajaran bahasa Indonesia di masa pandemi, penelitian yang dilakukan Handayani., \& Subakti (2020) guru di SDN 027 Samarinda ULU, belum begitu maksimal dalam pembelajaran daring di kelas III C. Penyebabnya karena media yang digunakan guru hanya WhatsApp sebagai media membagikan materi yang akan dipelajari peserta didik secara mandiri. Oleh karena itu, guru seharusnya mengombinasikan WhatsApp dengan media atau metode lainnya agar pembelajaran daring lebih menarik. Selain itu, guru juga diharapkan memberikan variasi dengan media atau metode lain sebagai strategi agar pembelajaran lebih atraktif dan bermakna.

Perbedaan penelitian sebelumnya dengan penelitian ini berkenaan dengan kedudukan WhatsApp yang tidak hanya dipakai sebagai media kunci. Hal ini karena WhatsApp sebagai media juga dipakai dengan dikombinasikan bersama mind mapping sebagai metodenya. Tujuannya adalah agar pembelajaran lebih bermakna dan menarik minat peserta didik sehingga mereka terhindar dari rasa jenuh. Pada dasarnya WhatsApp memang cukup sering digunakan sebagai alternatif pembelajaran di masa pandemi. Beberapa pembelajaran bahasa secara daring baik itu bahasa Indonesia, bahasa Inggris, maupun bahasa Arab juga ada yang memanfaatkan WhatsApp sebagai perangkat pendukung. Penelitian selanjutnya mengenai penggunaan whatsApp dalam pembelajaran bahasa Arab, menunjukan hasil pembelajaran dengan WhatsApp dapat dilakukan dengan memperhatikan segala aspek keterampilan yang akan diajarkan sehingga setiap aspek dapat diukur untuk kemudian dievaluasi (Mustofa, 2020). Sementara itu, Mandasari, \& Wulandari (2021) menyimpulkan bahwa aplikasi WhatsApp group merupakan salah satu solusi yang dinilai dapat membantu guru dan peserta didik dalam proses meningkatkan kemampuan dan penguasaan keterampilan berbahasa Inggris dengan tetap memperhatikan setiap kelebihan dan kekurangannya.

Dalam pembelajaran bahasa Indonesia, media WhatsApp dapat digunakan untuk 
meningkatkan kemampuan berliterasi peserta didik seperti hasil penelitian Sahidillah, \& Miftahurrisqi (2019) penggunaan WhatsApp sebagai media literasi digital meliputi tiga hal yaitu: (1) WhatsApp memudahkan ketika akan berbagi materi; (2) WhatsApp memungkinkan untuk digunakan dalam pembelajaran daring karena dukungan setiap fiturnya; serta (3) fitur WhatsApp story dapat digunakan untuk berbagi materi dan membantu aktivitas menyimak serta belajar menanggapi dengan memberikan komentar.

Selain melibatkan media WhatsApp, ada pula penelitian yang dilakukan dengan menggunakan mind mapping sebagai metode pembelajaran bahasa Indonesia. Keunggulan penggunaan metode mind map dalam pembelajaran bahasa indonesia aspek menulis teks berita yaitu: (1) mind mapping dapat memudahkan peserta didik dalam memahami materi menulis teks berita; (2) mind mapping dapat meningkatkan prestasi belajar peserta didik dalam menulis teks berita; dan (3) mind mapping dapat meningkatkan minat peserta didik dalam aktivitas pembelajaran (Kuncoro, 2015).

Sementara itu, Susilowati (2019) dalam penelitiannya mendapatkan hasil jika penelitian berjenis kuantitatif eksperimen tersebut menunjukkan bahwa metode mind mapping efektif terhadap pembelajaran menulis teks biografi pada peserta didik kelas X MA Tarbiyatul Mubtadiin Wilalung Kabupaten Demak. Selanjutnya, penggunaan teknik mind mapping pada keterampilan menulis ringkasan siswa dalam pembelajaran bahasa Indonesia dapat dijelaskan (1) peserta didik lebih antusias dalam pembelajaran karena pada kelas treatment peserta didik dibimbing dalam pembuatan ringkasan dengan mind mapping sebagai metodenya sehingga hasil post test jauh lebih baik jika dibandingkan dengan pretest; (2) penggunaan metode mind mapping berpengaruh pada pembelajaran menulis teks ringkasan; dan (3) terdapat perbandingan yang signifikan antara peserta didik yang diajarkan dengan menggunakan metode mind mapping dan yang tidak menggunakannya (Saharah, \& Indihadi, 2019).

Berdasarkan paparan di atas media WhatsApp dan metode mind mapping sudah beberapa kali dipakai dalam aktivitas pembelajaran keterampilan berbahasa baik bahasa Indonesia, Inggris, maupun bahasa yang lain. Namun, penelitian yang memfokuskan pada voice note sebagai media utama dan dikombinasikan dengan metode mind mapping merupakan hal baru yang patut dicoba. Akan tetapi, paduan media dan metode ini tidak serta-merta digunakan dalam setiap pembelajaran. Harus ada kesesuaian karakter antara aplikasi sebagai media dan materi yang diajarkan sehingga memberikan hasil yang optimal.

Lebih lanjut mengenai penelitian yang mengombinasikan voice note dan mind mapping dibahas pada paparan pembahasan. Sebagai acuan maka tujuan penelitian ini adalah untuk mengetahui: (1) teknis pembelajaran bahasa Indonesia dengan kombinasi voice note dan mind mapping; serta (2) keunggulan dan kelemahan pelaksanaan pembelajaran bahasa Indonesia dengan kombinasi voice note dan mind mapping.

\section{2 | METODE PENELITIAN}

Jenis penelitian ini adalah deskriptif kualitatif. Sementara itu, data penelitian ini dikumpulkan dengan menggunakan teknik analisis dokumen atau content analysis yang dilakukan dengan mengumpulkan data dari berbagai sumber yang kemudian dianalisis dengan teknik analisis interaktif. Adapun dalam Sugiyono (2009) aktivitas yang dilakukan dalam analisis data adalah sebagai berikut: (1) data reduksi (data reduction), (2) displai data (data display), dan (3) verifikasi data (conclusion drawing/verification). Data dalam penelitian ini berasal dari observasi, studi pustaka, dan wawancara dengan sumber terkait. 


\section{3 | HASIL DAN PEMBAHASAN}

\section{Teknis Pembelajaran Bahasa Indonesia dengan Voice Note dan Mind Mapping}

Pembelajaran bahasa Indonesia dengan kombinasi voice note dan mind mapping ini telah diterapkan pada pokok bahasan teks laporan percobaan di MTsN 4 Boyolali Kelas IX tahun pelajaran 2020/2021. Terdapat empat kelas yang diajar dengan kombinasi media dan metode tersebut yaitu IXA, IXB, IXC, dan IXD. Keempat kelas tersebut merupakan kelas heterogen dengan perbandingan jumlah siswa dan siswi yang relatif sama.

Peserta didik kelas IX MTsN 4 Boyolali tahun pelajaran 2020/2021 telah memulai aktivitas pembelajaran daring mulai Maret 2021 ketika mereka masih kelas VIII semester genap. Pada waktu itu Indonesia dinyatakan darurat Covid 19 sehingga pemerintah pada akhirnya memutuskan bahwa segala aktivitas pendidikan untuk sementara dilaksanakan dari rumah masing-masing hingga situasi dan kondisi dinyatakan stabil. Namun, hingga kenaikan kelas, Covid 19 masih melanda hingga pada akhirnya pembelajaran daring diperpanjang masanya. Oleh karena itu, siswa kelas IX MTsN 4 Boyolali tahun pelajaran 2020/2021 kembali melaksanakan aktivitas pembelajaran secara daring.

Teks laporan percobaan atau disebut juga teks laporan hasil penelitian merupakan suatu teks yang ditulis dengan melihat kondisi sebenarnya setelah melakukan kegiatan eksperimen. Menurut Mahsun (2014) teks laporan percoban merupakan salah satu jenis laporan ilmiah yang memiliki tujuan sosial dengan memberikan laporan suatu kajian terhadap objek ilmiah yang dikerjakan secara sistematis, empiris, kritis, dan terkontrol khususnya pada tahapan pengumpulan, analisis, dan penyajian data. Pada pembelajaran luring kegiatan menulis teks laporan percobaan di MTsN 4 Boyolali benar-benar dilakukan secara empiris yaitu dengan mengadakan eksperimen yang sebenarnya. Hal ini dilakukan untuk melatih siswa dalam melakukan kegiatan penelitian sekaligus praktik menulis laporan percobaan.

Gambaran umum pelaksanaan pembelajaran menulis teks laporan percobaan pada siswa kelas IX MTsN 4 Boyolali yang diterapkan sebelum masa pandemi Covid-19 adalah dengan menyampaikan materi dan diskusi beserta penguatan teori. Pada tahapan ini peserta didik setidaknya dapat memahami inwal hakikat teks laporan percobaan, struktur, unsur kebahasaan, dan langkah-langkah pembuatannya. Kemudian aktivitas pada pertemuan selanjutnya adalah dengan membentuk kelompok eksperimen dengan mengadakan percobaan uji karbohidrat, lemak, dan protein pada bahan makanan yang dibawa oleh masing-masing kelompok. Kemudian, setelah peserta didik dinyatakan selesai melaksakan eksperimen langkah selanjutnya adalah dengan menulis teks laporan percobaan. Semua aktivitas tersebut dilakukan di sekolah dengan pengawasan dan bimbingan guru.

Pelaksanaan pembelajaran juga dipengaruhi dengan keterlibatan orang tua dalam proses pembelajaran karena terpaan media baru kepada orang tua berpengaruh terhadap perilaku anak (Setiyaningsih et al., 2021). Sehingga pelaksanaan pembelajatan dengan materi yang sama pada pembelajaran daring berbeda dengan pembelajaran luring. Berikut ini adalah kegiatan pembelajaran bahasa Indonesia di kelas IX dengan materi teks laporan percobaan yang dilaksakan secara daring dengan mengombinasikan media voice note pada aplikasi WhatsApp dengan metode mind mapping. Langkah-langkah pembelajaran daring tersebut antara lain sebagai berikut: (1) guru menghimpun nomor WhatsApp peserta didik kemudian membuat WhatsApp Group (WAG) yang berisi semua peserta didik yang mengikuti mata pelajaran terkait, dalam hal ini adalah mata pelajaran bahasa Indonesia; (2) guru menyampaikan instruksi mengenai aktivitas pembelajaran yang akan dilakukan dengan menggunakan mind mapping dan voice note; (3) guru membuat mind mapping pada kertas gambar ukuran A3 yang berisi materi inti yang akan disampaikan dan harus dikuasai oleh peserta didik; (4) mind mapping yang telah dibuat guru difoto dan dikirimkan di WAG sebagai contoh mind mapping yang akan dibuat oleh peserta didik; (5) peserta didik membuat mind 
mapping versi sendiri tetapi dengan acuan contoh mind mapping yang telah dibuat guru; (6) peserta didik harus menyelesaikan mind mapping selama satu pekan; (7) pekan berikutnya guru dan peserta didik akan bersama berada dalam kelas virtual yang sama dalam rangka melaksanakan pertemuan pembelajaran berikutnya; (8) pada pertemuan pembelajaran tersebut guru menyampaikan materi secara sistematis dengan panduan mind mapping; (9) penjelasan mengenai materi yang terdapat pada mind mapping disampaikan melalui voice note; (10) aktivitas yang dilakukan peserta didik adalah menyimak penjelasan guru disertai dengan mengamati mind mapping yang telah dibuat; dan (11) jika ada hal-hal yang kurang dipahami peserta didik dapat menggunakan fitur yang sama untuk menyampaikan pertanyaan kepada guru.

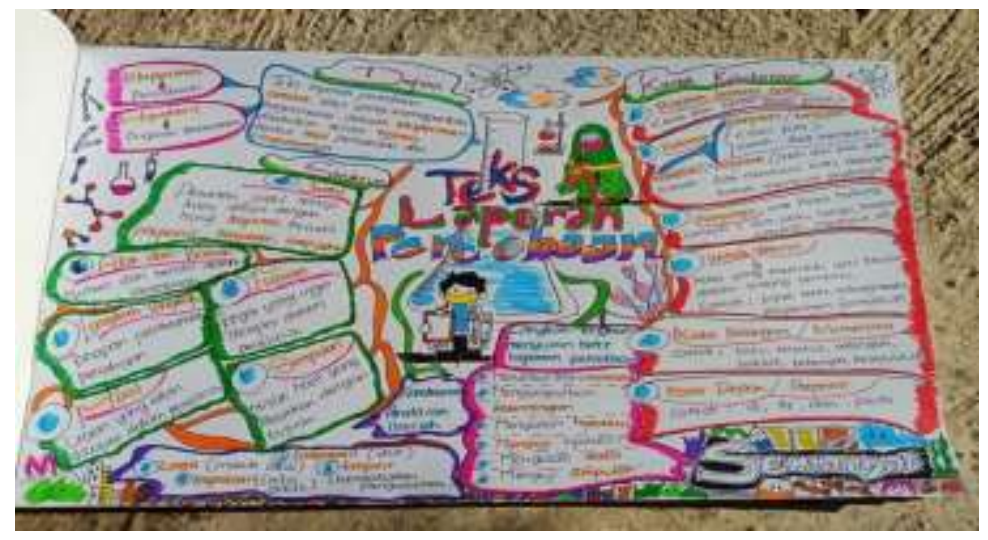

\section{Gambar 1. Mind Mapping yang Dibuat Guru}

Langkah-langkah pembelajaran tersebut diterapkan pada pembelajaran secara daring khususnya untuk penyampaian materi dan penguatan teori. Selebihnya untuk praktik eksperimen peserta didik diinstruksikan untuk membuat eksperimen sederhana di rumah masing-masing atau jika tidak memungkinkan mereka diberikan kebebasan untuk mengingat kembali eksperimen yang sudah mereka lakukan pada mata pelajaran IPA. Pada tahapan ini guru memberikan kelonggaran kepada peserta didik karena pada hakikatnya hal semacam itu perlu dilakukan untuk memberikan kemudahan pada peserta didik dalam aktivitas pembelajaran jarak jauh. Tidaklah berlebihan jika disampaikan bahwa inti pembelajaran daring adalah harus bermakna tetapi tidak memberatkan peserta didik.
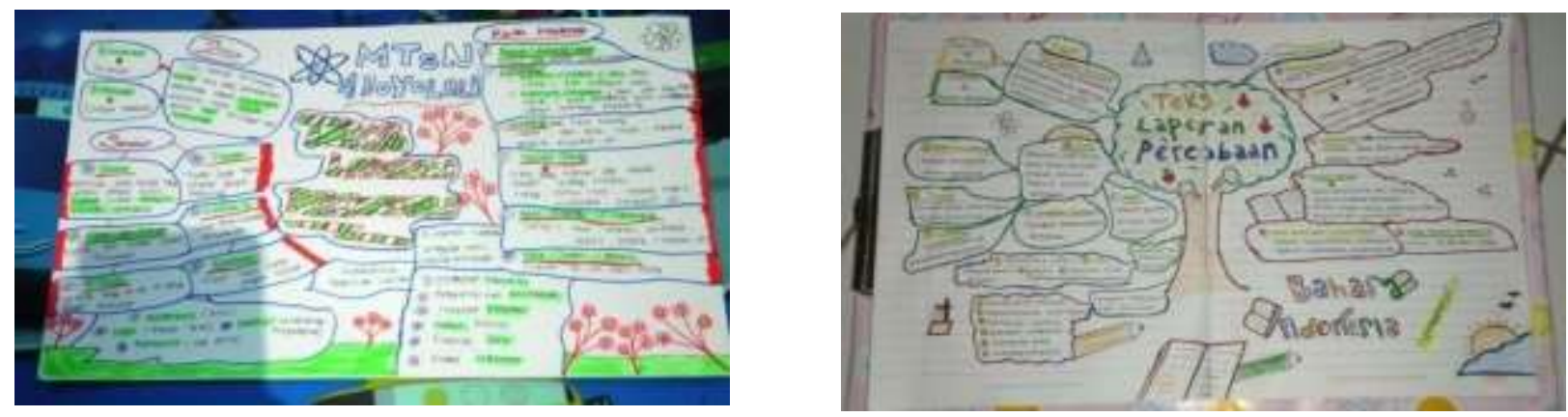

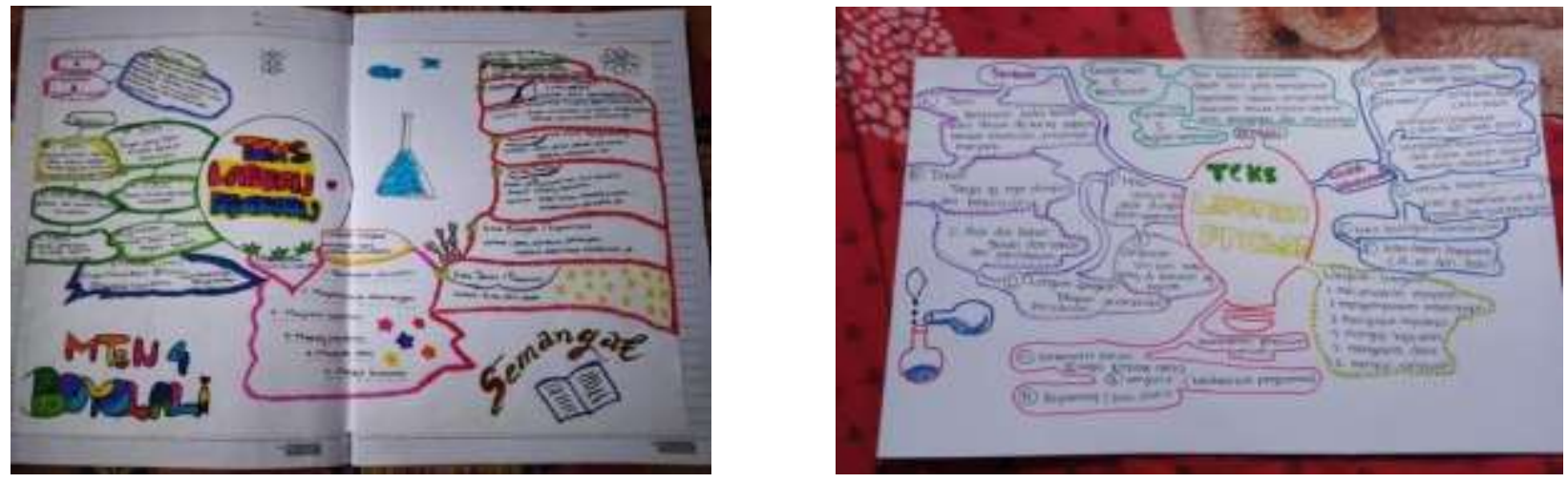

\section{Gambar 2. Mind Mapping Karya Peserta Didik}

Ada beberapa catatan penting dalam pembelajaran ini. Pertama, pelaksanaan pembelajaran secara daring pada materi menulis teks laporan percobaan dengan voice note dan mind mapping ini dilakukan untuk tahapan penguatan teori sebagai bekal untuk menulis teks laporan percobaan. Kedua, tugas peserta didik selanjutnya adalah dengan menulis teks laporan percobaan berdasarkan eksperimen sederhana yang bisa dilakukan peserta didik di rumah masing-masing. Peserta didik diberikan kebebasan dalam menentukan proyek eksperimen yang dikerjakan. Ketiga, selama pembelajaran daring guru memberikan pelayanan kepada peserta didik yang membutuhkan bantuan dan pendampingan dalam belajar, tentunya pelayanan tersebut dilakukan secara daring.

\section{Keunggulan dan Kelemahan Pembelajaran dengan Voice Note dan Mind Mapping}

Pembelajaran secara daring seakan-akan menuntut peran aktif guru untuk berinovasi dalam berstrategi agar aktivitas pembelajaran lebih menyenangkan dan memberikan hasil yang optimal meskipun dengan segala keterbatasan. Dalam berinovasi guru juga harus terlebih dahulu menguasai hal-hal yang akan diterapkan dalam pembelajaran sehingga ketika diaplikasikan dalam kegiatan belajar mengajar bersama peserta didik akan berjalan lancar. Pada dasarnya ada dua prinsip yang dapat dijadikan patokan dalam berinovasi yaitu dengan bereksperimen mencari hal baru atau dengan menajamkan kepekaan indera dengan mengombinasikan hal-hal yang sudah ada. Menemukan hal yang baru mungkin membutuhkan waktu yang lama dari tahapan penemuan, uji coba, hingga evaluasi. Oleh karena itu, sebagai langkah awal dalam berinovasi guru dapat menganalisis hal-hal yang sudah ada, mencari masing-masing karakteristiknya, mengombinasikannya, dan menerapkannya pada aktivitas pembelajaran yang dipandang cocok.

Voice note pada aplikasi WhatsApp dan mind mapping merupakan dua hal yang sudah ada sebelumnya. Keduanya sama-sama pernah digunakan dalam aktivitas pembelajaran. Namun, kombinasi keduanya sebagai media dan metode pada pembelajaran daring patut untuk dicoba karena ada beberapa kelebihan yang mendukung aktivitas pembelajaran daring berjalan dengan lebih menyenangkan dan bermakna. Penggunaan media voice note dalam pembelajaran bahasa Indonesia memiliki kelebihan dan kelemahan. Adapun nilai positif kombinasi keduanya, adalah bahwa mind mapping membuat pembelajaran lebih berbeda jika dibandingkan dengan pembelajaran jarak jauh yang hanya memberikan tugas berupa instruksi untuk membaca rangkuman semata atau perintah untuk mengerjakan tugas pada lembar kerja siswa. Mind mapping merupakan bentuk visual yang dapat menjadikan peserta didik melakukan suatu aktivitas tanpa harus memikirkan masalah koneksi internet dan kuota yang dibutuhkan. Hal ini tentunya berbeda jika peserta didik mengaktifkan bentuk visual lain seperti tugas dari guru untuk mengamati video pembelajaran di YouTube. Mind mapping dan video memiliki persamaan dalam hal bentuk visualnya tetapi YouTube dipandang lebih memberatkan karena berhubungan dengan koneksi 
internet dan kuota yang dibutuhkan.

Keunggulan metode mind mapping lainnya adalah pembelajaran lebih menarik karena pembuatan mind mapping merupakan aktivitas yang menyenangkan. Peserta didik diberikan kebebasan dalam membuat mind mapping dengan versi mereka sendiri. Mereka dapat menambahkan gambar, bermain warna dan garis, bahkan dapat mengombinasikannya dengan menambahkan stiker ataupun potongan gambar yang ditempelkan pada mind mapping. Kegiatan ini tidak hanya menyenangkan untuk dilakukan tetapi juga dapat mengasah kreativitas peserta didik. Mind mapping dapat membantu peserta didik dalam memecahkan masalah, dapat saling bertukar pikiran mengenai ide-ide kreatif, mampu menajamkan daya ingat, lebih terampil dalam membuat catatan, dan meningkatkan keterampilan membaca terlebih jika dibantu dengan media berbasis web (Meivi et al., 2019; Triono \& Setiyaningsih, 2017).

Kaitannya dengan masalah konten mind mapping dinilai baik digunakan karena berisi poinpoin penting suatu materi yang divisualisasikan sehingga lebih mudah diingat dan dipahami. Hal baik lainnya adalah ketika peserta didik membuat mind mapping maka tanpa disadari mereka telah melakukan kegiatan membaca lebih dari satu kali. Fakta semacam ini dapat menjadikan peserta didik lebih memahami materi pembelajaran karena media ini membuat sajian materi menjadi lebih ringkas. Mind mapping memungkinkan peserta didik mengulang-ulang pembelajaran karena ketika mereka membuat mind mapping tahap demi tahap maka mereka secara tidak langsung akan membaca isi materi tersebut. Jika terdapat pengulangan seperti ini maka peserta didik akan mengingat dan memahami isi mind mapping sehingga berpotensi meningkatkan prestasi belajar. Senada dengan Nurhabibah (2021) bahwa mind mapping dapat digunakan sebagai sarana pendukung atau alat bantu dalam kegiatan belajar mengajar yang tujuannya untuk meningkatkan minat, pemahaman konsep-konsep pembelajaran, hingga membantu meningkatkan prestasi belajar baik siswa maupun mahasiswa.

Mind mapping memiliki sifat yang atraktif yaitu salah satunya dapat memberikan kebebasan kepada peserta didik untuk berekspresi. Sifatnya yang demikian ini dapat digunakan sebagai sistem terapi bagi peserta didik yang mengalami kejenuhan dalam menjalani aktivitas pembelajaran jarak jauh. Menurut Syawaludin, \& Sutama (2020) penggunaan peta konsep atau yang disebut juga dengan mind map ini memiliki dampak yang cukup signifikan pada aktivitas pembelajaran baik masa pandemi maupun pascapandemi Covid-19. Jadi, pada dasarnya dalam pembelajaran luring maupun daring, metode mind mapping dapat digunakan.

Kombinasi antara voice note dengan mind mapping tidak hanya memiliki keunggulan pada segi penggunaan metodenya. Hal ini karena dari segi media yaitu voice note juga memiliki kelebihan, antara lain: (1) voice note dapat membantu peserta didik dalam menghadirkan figur guru dalam ruang belajar mereka meskipun hanya melalui suara atau audio; (2) voice note memungkinkan guru memberikan penjelasan lebih rinci sehingga diharapkan peserta didik dapat lebih memahami; dan (3) voice note memungkinkan peserta didik untuk secara langsung dan cepat ketika berargumen, mengajukan pertanyaan, ataupun ketika menjawab pertanyaan-pertanyaan yang dilontarkan guru.

Kombinasi voice note dan mind mapping memang banyak memiliki nilai postif. Namun, tidak dapat dipungkiri bahwa dalam uji coba yang dilakukan di MTsN 4 Boyolali pelaksanaan pembelajaran ini juga ditemukan beberapa kekurangan. Berikut ini beberapa kekurangan yang ditemukan, yaitu: (1) tidak semua peserta didik membuat mind mapping karena mereka beranggapan jika dalam pembelajaran daring guru terkesan lebih longgar sehingga tidak akan melakukan kontrol pada setiap aktivitas dan pekerjaan peserta didik; (2) beberapa peserta didik membuat mind mapping tetapi dengan asal-asalan dengan dalih instruksi yang diberikan adalah sesuai versi peserta didik masing-masing; (3) ada beberapa peserta didik yang tidak memiliki perangkat eletronik pendukung belajar baik laptop maupun telepon pintar sehingga menjadikan alasan untuk tidak mengikuti pembelajaran daring; (4) terdapat peserta didik yang beralasan tidak 
mengunduh voice note karena menghabiskan kuota; dan (5) guru masih menghadapi kendala dalam mengontrol peserta didik pada pembelajaran daring.

Terlepas dari ditemukannya kelemahan, secara umum pembelajaran dengan kombinasi voice note dan mind mapping ini berjalan lancar. Pengalaman belajar yang terjadi di MTsN 4 Boyolali memberikan fakta bahwa pembelajaran berjalan dengan baik. Bahkan, waktu dua jam pelajaran yang diagendakan pada setiap pertemuan tidak terasa hingga melebihi batas waktu. Sementara itu, kegiatan pembelajaran jauh lebih hidup karena banyak peserta didik yang berperan aktif dalam pembelajaran. Mereka memberikan respon positif terhadap pembelajaran dengan berlomba-lomba menjawab pertanyaan guru dan mengajukan pertanyaan apabila ada hal yang belum dipahami. Ketika guru melontarkan pertanyaan terkait pembelajaran semacam ini pun peserta didik me respon positifnya. Dengan analogi tersebut apabila kombinasi kedua sarana tersebut diterapkan pada mata pelajaran atau materi yang lain maka akan memberikan nilai positif juga.

\section{4 | SIMPULAN DAN SARAN}

Di tengah situasi pandemi covid 19 dunia pendidikan dihadapkan dengan berbagai situasi tidak menentu dan keterbatasan terkait sarana dan prasarana. Guru sebagai fasilitator harus mampu berstrategi dalam menemukan inovasi agar pembelajaran daring lebih menyenangkan dan bermakna. Kombinasi voice note pada aplikasi WhatsApp dengan mind mapping dapat dijadikan sebagai alternatif solusi dalam pembelajaran bahasa Indonesia. Keduanya memiliki hubungan komplementer yang saling mendukung sehingga aktivitas belajar mengajar dapat berjalan dengan lancar dan memberikan hasil belajar yang lebih baik. Namun, pembelajaran dengan voice note juga masih ditemukan celah sehingga perlu dicari solusi lain agar paduan media dan metode ini semakin baik dan memperkecil adanya kelemahan. Meskipun demikian, pembelajaran dengan voice note dan mind mapping ini tetap patut untuk diterapkan. Dari hasil uji coba kelebihan pembelajaran ini masih lebih banyak jika dibandingkan dengan kelemahannya. Oleh karena itu, saran yang dapat disampaikan adalah hendaknya paduan voice note dan mind mapping dapat diaplikasikan pada pembelajaran materi lain atau bahkan mata pelajaran lainnya. Tentu saja terlebih dahulu harus dianalisis aspek kesesuaiannya agar aktivitas pembelajaran tidak terkesan dipaksakan. Aktivitas pembelajaran yang dipaksakan hanya akan berdampak pada peserta didik yang merasa tertekan. Hal ini tidak bisa dibiarkan karena akan berpengaruh pada kondisi psikis dan prestasi belajar peserta didik.

\section{RE FERE N S I}

Abidah, A., Hidaayatullaah, H. N., Simamora, R. M., Fehabutar, D., \& Mutakinati, L. (2020). The Impact of Covid-19 to Indonesian Education and Its Relation to the Philosophy of "Merdeka Belajar." Studies in Philosophy of Science and Education, 1(1), 38-49. https://doi.org/https://doi.org/10.46627/sipose.v1i1.9

Areeisty, K., Hasanuddin, \& Sarong, M. A. (2020). The implementation of problem-based learning with mind mapping to improve students' learning motivation. Journal of Physics: Conference Series, 1460(1). https://doi.org/https://doi.org/10.1088/1742-6596/1460/1/012061

Dewanta, A. A. N. B. J. (2019). Pemanfaatan Aplikasi Tik Tok Sebagai Media Pembelajaran Bahasa Indonesia. Jurnal Pendidikan Dan Pembelajaran Bahasa Indonesia, 8(2), 5- 102.

Ering, M. (2020). Gereja Rumah di Masa Pandemi Covid-19: Manajemen Resiko dan Mitigasi Bencana Non Alam. Pute Waya: Sociology of Religion Journal, 10(1), 1-14. 
Ernawati, I. R. (2020). Pendidikan dan Pembelajaran Bahasa Indonesia Online. Jurnal Pendidikan Dan Pembelajaran, 9(2), 103-112.

Fahmi, M. H. (2020). KOMUNIKASI SYNCHRONOUS DAN ASYNCHRONOUS DALAM ELEARNING PADA MASA PANDEMIC COVID-19. Jurnal Nomosleca, 6(2), 146-158.

Handayani, E. S., \& Subakti, H. (2020). Analisis Pembelajaran Daring Bahasa IndonesiaPada Masa Pandemi Covid-19 Di Sdn 027 Samarinda Ulu. Jurnal Basataka (JBT), 3(2), 81-89.

Juniartini, I. R. (2020). Pemanfaatan Aplikasi Google Meet Dalam Keterampilan Menyimak Dan Berbicara Untuk Pembelajaran Bahasa Pada Masa Pandemi Covid-19. Jurnal Pendidikan Dan Pembelajaran Bahasa Indonesia, 9(2), 133-141.

Kuncoro, I. (2015). PENGGUNAAN METODE MIND MAP DALAM PEMBELAJARAN BAHASA INDONESIA ASPEK MENULIS TEKS BERITA UNTUK MENINGKATKAN PRESTASI DAN MINAT BELAJAR SISWA KELAS VIIIB SMP NEGERI 3 KEBASEN (Vol. 2). SMPn 3 Kebasen.

Mahsun. (2014). Teks dalam Pembelajaran Bahasa Indonesia Kurikulum 2013 1st ed (1st ed.). Rajawali Pers.

Mandasari, Y. P., \& Wulandari, E. (2021). Teaching ESP during emergency remote learning (ERL): Best practices. ELT Forum: Journal of English Language Teaching, 10(2), 154-162.

Meivi Sesanelvira, A. D. I., Mulyono, S., \& S. (2019). Improving Food Safety Behavior through Mind Map Methods in School-Age Children. Comprehensive Child and Adolescent Nursing, 42(1), 97-107. https://doi.org/https://doi.org/10.1080/24694193.2019.1578301

Mustofa, M. A. (2020). Analisis Penggunaan WhatsApp Sebagai Media Pembelajaran Bahasa Arab di Era Industri 4.0. Arabiyatuna: Jurnal Bahasa Arab, 4(2), 333.

https://doi.org/https://doi.org/10.29240/jba.v4i2.1805

Nilasari, K. E. (2020). Pembelajaran Bahasa Indonesia di masa pandemi di COVID 19. Paedagogia, 5(36), 27-39.

Nurazizah, H., Friatin, L. Y., \& Sugiarto, B. R. (2019). Whatsapp Voice Note in Speaking Class. Journal of English Education and Teaching, 3(3), 343-360. https://doi.org/https://doi.org/10.33369/jeet.3.3.343-360

Nurhabibah, S. (2021). Penerapan Metode Mind Mapping Berbasis Daring Untuk Meningkatkan Hasil Belajar Mahasiswa PGSD di Masa Pandemi Covid-19. Jurnal Pendidikan IImu Sosial, 30(1), 13-22.

Purbasari, R. J. (2013). "Pengembangan Aplikasi Android Sebagai Media Pembelajaran Matematika Pada Materi Dimensi Tiga Untuk Siswa SMA Kelas X". Jurnal Pendidikan Matematika, 1(2).

Saharah, S., \& Indihadi, D. (2019). PEDADIDAKTIKA: JURNAL ILMIAH PENDIDIKAN GURU SEKOLAH DASAR Penggunaan Teknik Mind Mapping pada Keterampilan Menulis Ringkasan Siswa dalam Pembelajaran Bahasa Indonesia. (Vol. 6, Issue 1). Jurnal UPI Education, 6(1). http://ejournal.upi.edu/index.php/pedadidaktika/index

Sahidillah, M. W., \& Miftahurrisqi, P. (2019). Whatsapp sebagai Media Literasi Digital Siswa. Jurnal VARIDIKA, 1(1), 52-57. https://doi.org/https://doi.org/10.23917/varidika.v1i1.8904

Setiyaningsih, L. A., \& Jatmikowati, S. H. (2019). Media Baru Dalam Komodifikasi Waktu Luang Ibu Rumah Tangga. ETTISAL: Journal of Communication, 4(1), 23-32.

Setiyaningsih, L. A. (2020). MEDIA PANICS IBU RUMAH TANGGA SETELAH MENGAKSES BERITA COVID-19 (2020). Jurnal Nomosleca, 6(2), 101-110.

http://jurnal.unmer.ac.id/index.php/n/article/view/4721/2594

Setiyaningsih, L. A., Fahmi, M. H., \& Molyo, P. D. (2021). Selective Exposure Media Sosial Pada 
Ibu dan Perilaku Anti Sosial Anak. Jurnal Komunikasi Nusantara, 3(1), 1-11.

https://doi.org/10.33366/jkn.v3i1.65

Sugiyono. (2009). Metode Penelitian Kuantitatif, Kualitatif dan $R$ and D. Penerbit Alfabeta.

Sulhin, I. (2020). COVID-19, PEMENJARAAN BERLEBIHAN, DAN POTENSI KATASTROFE KEMANUSIAAN. Jurnal Hukum \& Pembangunan, 50(2), 400.

https://doi.org/https://doi.org/10.21143/jhp.vol50.no2.2588

Susilowati, D. (2019). KEEFEKTIFAN METODE MIND MAPPING DALAM PEMBELAJARAN MENULIS TEKS BIOGRAFI. Jurnal Pendidikan Dan Pembelajaran Bahasa Indonesia, 8(2), 21-32.

Syawaludin, R., \& Sutama, S. (2020). PENYUSUNAN PETA KONSEP MEMPERMUDAH BELAJAR SISWA SELAMA MASA PANDEMI COVID-19. Manajemen Pendidikan, 15(2), 8998.

Triono, M. A., \& Setiyaningsih, L. A. (2017). Desain Disonansi Kognitif Sebagai Faktor Anteseden Untuk Penguatan Kualitas Informasi Pada Website. Seminar Nasional Sistem Informasi, 1(1), 71-79. http://eprints.unmer.ac.id 